\title{
Voluntary Intellectual Capital Disclosure: A Theoretical Test of Proprietary Cost
}

\author{
Wawan Sadtyo Nugroho ${ }^{1}$, Barkah Susanto ${ }^{2}$, Marlina Kurnia ${ }^{3}$, Annisa Hakim Purwantini ${ }^{4}$ \\ \{wawan.sn11@gmail.com ${ }^{1}$ \}
}

Accounting Department, Muhammadiyah Magelang University, 57611, Indonesia ${ }^{1,2,4}$

Management Department, Muhammadiyah Magelang University, 57611, Indonesia ${ }^{3}$

\begin{abstract}
Cost of equity could be minimalized by intellectual capital disclosure. Quality of information in this intellectual capital disclosure depends on the cost of proprietary, cost of information, and the relevance to get the information. This study was conducted to give empirical evidences about model analyze of intellectual capital to the cost based on theory of signaling and theory of proprietary cost. This study used design of quantitative research. Samples in this study were the enterprises that were registered in Indonesian Bursary Effect, except to the enterprises of financial industry in 2015 - 2019. Sampling extraction was performed by method of purposive sampling. Data analyzing used statistic of descriptive analyzes and regression of moderating. Test of hypothesis was conducted by analyzing technic of test of comparing coefficients across regressions. The results of data analysis of the research showed that increasing the disclosure of voluntary intellectual capital could decrease cost of equity. The low cost of proprietary could strengthen negative effects of the intellectual capital disclosure on cost of equity. The low cost of information could not strengthen negative effects of the intellectual capital disclosure on cost of equity. The high relevance of information could not strengthen negative effects of the intellectual capital disclosure on cost of equity.
\end{abstract}

Keywords: Voluntary disclosure, intellectual capital, cost of equity, cost of proprietary

\section{Introduction}

Disclosure becomes one of effective tools of management to deliver information to the external parties, including the investor [8]. In addition to the informations that have to be disclosured, there are other informations that need to be disclosured voluntarily. The voluntary disclosure could give more relevant description when it is happened the executive change in the enterprise or price decline of stock, so that the management still could control the stock price of enterprise. Intellectual capital could be an information that could be disclosure voluntarily and could increase the stock price. The investors tend to pay the higher stock in enterprise with more intellectual resources compared than enterprise with low intellectual resources [34].

Based on signaling theory, enterprise with good performance tends to give easier disclosure voluntarily [8]. Some researchers have conducted research related on cost of equity that were influenced by intellectual capital disclosure. The research that was conducted by [9][10] [35][32][33][44][12] and [15] showed that the intellectual capital disclosure could give negative effects on cost of equity. It was caused by many samples of enterprise that largely disclosured 
intellectual capital in the report and given the relevant information to the investor in considering the enterprise, so that the enterprises could gain benefits from getting lower cost of equity.

Nevertheless, [31] in their research have seen the voluntary disclosure in two aspects, the information disclosure that was oriented to the future and the information disclosure related to the enterprise history. Results of the research showed that there were negative effects of the information disclosure that was oriented to the future on cost of equity, whereas cost of disclosure of historical information had positive effects on cost of equity. The research that was conducted by [11] and [42] showed that the intellectual capital disclosure did not impact significantly on cost of equity.

The research of [39] have found the implication of proprietary cost and information relevance to the disclosure. Then, the research developed hypothesis of proprietary cost and saving cost of acquisition of private information in this disclosure. The result was consistent with the proprietary cost theory. The proprietary cost would decrease the disclosure of full information. The proprietary cost could help managers to minimalize the probability of decreasing stock price because of the interception of information as consequence of bad news or to avoid the realization of proprietary cost.

The research related to proprietary cost by [47][39][25][36] and [2], still discussed proprietary cost comprehensively, not yet explained effect of high or low proprietary cost with strong effect to intellectual capital disclosure in cost of equity. This research used enterprise with proprietary cost, cost of information, and relevance of information in high category and enterprise with proprietary cost, cost of information, and relevance of information in low category. The use of two enterprises with high and low category has not been conducted previously, so that this study results could show the results of level of effects of proprietary cost, cost of information, and high or low relevance of information on cost of equity.

In general, this research was purposed to find empirical evidences about model analysis of intellectual capital disclosure on cost of equity, based on proprietary cost theory. The specific purpose of this research was to give empirical evidences about effect of intellectual capital disclosure on cost of equity. In addition, this research was also purposed to analyze negative effect of the intellectual capital disclosure on cost of equity that was moderated by level of proprietary cost, cost of information, and relevance of information.

In addition, signaling theory was considered to be unable to explain disclosure that could give positive effect and even did not influence on cost of equity. The limitation of signaling theory in explaining effects of disclosure on cost of equity could be explained by using proprietary cost theory. The proprietary cost theory explained that without cost related to disclosure, enterprise would get incentive to perform disclosure of information voluntarily [47].

Theoretic contribution in this research was capable to increase the reference in explaining the relevance between signaling theory with cost of equity, that was effect of intellectual capital disclosure on cost of equity. The practical contribution of this research was capable to increase reference and to be managerial consideration in making right decision and policy to surprises cost of equity through the intellectual capital disclosure. The policy contribution of this research was helping regulator and standard maker in making policy and regulation related to the disclosure of financial report.

\subsection{Intellectual capital disclosure impacted negatively on cost of equity}

Signaling theory suggested how an enterprise give signal to the user of financial report. This signal could be information of what was conducted by management to realize the owner desire [46]. Information of intellectual capital that could be disclosured was human equity [18]. 
It is convinced that the enterprise that could manage its intellectual resources could create additional values and competitive excellence by performing innovation, research and development that would influence the increase of financial performance of the enterprise. Second element in intellectual capital was disclosure of structural equity such as structure and process that was developed and applied to employees in order that they could be more productive, effective, and innovative [12]. The last element was relationship equity that was one of intellectual equities of relationship between enterprise and other parties [12].

The research related to intellectual capital disclosure has been conducted by [12] that found that there was significant and negative relationship between intellectual capital disclosure that was measured by two components (equity of human and structural) and cost of equity. The research result of [35] showed that the intellectual capital disclosure was proven to have negative effect on cost of equity. The research conducted by [10] also showed that the disclosure influenced negatively on cost of equity. Based on the description, the first hypothesis in this research is:

$\mathrm{H}_{1}$ : Intellectual capital disclosure influences negatively on cost of equity.

Proprietary cost did not only give benefit for enterprise, but also impacted to the issued cost related to release of information [36]. Explained that proprietary cost could give negative effect to the voluntary disclosure that was conducted by management [25].

In addition, the intellectual capital disclosure based on the research conducted by [32], had negative effects on cost of equity. If it was related to the research result that was conducted by [36] about proprietary cost and voluntary disclosure, proprietary cost was strongly relevant and could limit the enterprise support to give information of segment to the market, it meant that the high proprietary cost could be considered for the enterprise to give intellectual capital disclosure voluntarily. Based on the argument, it could be made hypothesis such as following:

$\mathrm{H}_{2}$ : Negative effect of intellectual capital disclosure on cost of equity in enterprise with lower proprietary cost was greater than enterprise with high proprietary cost.

The intellectual capital disclosure as private information was important for the enterprise, such as human resources and applied technology, so that it could become basic of investment decision, decreasing risks of estimation, getting appropriate stock price, and decreasing cost of equity [43]. Have explained that the issued cost was not only cost of purchased information, but also included cost of analysis, maintenance, and classification of information [14]. Therefore, the amount of the issued cost of information could give effect that was given by intellectual capital disclosure on cost of equity.

[45] said that the quality of disclosure related to the cost and benefit of information was similar in proprietary cost theory. The disclosure of qualified information also needed professional persons, because they could increase the value of annual report, where the annual report was used by investors as matter of consideration to invest. Although it was happened the increase of information cost because using professional persons in the disclosure, it could decrease the cost of equity. Based on the argument, it could make hypothesis of this research such as following:

$\mathrm{H}_{3}$ : Negative effect of intellectual capital disclosure on cost of equity in enterprise with low cost of information is greater than enterprise with high cost of information.

The relevance of information was a multidimensional attribute that was strongly related to the given benefit of information to the user [17]. The attribute consisted of associative capacity between information and market value of enterprise, accurate time of information, and content 
of information. The relevant information meant that the supplied or disclosure information was appropriate with the real enterprise. Disclosuring relevant information could withdraw more stockholders and finally it could impact to stock value of the enterprise [40]. The relevant disclosure of information could help the investors in controlling the enterprise to the initial contract agreement [25]. When the supplied information was relevant, it would make possible to support the intellectual capital disclosure voluntarily to become greater, it meant that it could increase the trust of external parties about the performance of enterprise. Therefore, the intellectual capital disclosure could strongly press the cost of equity through the existence of high relevance of information.

$\mathrm{H}_{4}$ : Negative effect of intellectual capital disclosure on cost of equity in enterprise with high relevance is greater than enterprise with low relevance of information.

\section{Method}

\subsection{Population, samples, and analysis}

The sampling enterprise was conducted using method of purposive sampling, with the following sample criteria: 1) the enterprise was registered in Indonesian Bursary Effect, except to enterprise of financial and investment industry; 2) the enterprise that issued financial report and annual report completely during the period of $2015-2019 ; 3)$ the enterprise that did not experience delisting during the period of 2015 - 2019; 4) the enterprise that did not experience suspend by Indonesian Bursary Effect during the period of 2015 - 2019.

\subsection{Data of research}

The used data in this research was secondary data that was financial report and annual report. The data was derived from the site of www.idx.co.id and each enterprise sites. The data that was derived from financial report consisted of data related to account of cost of equity, proprietary cost, cost of information, and relevance of information, whereas from annual report was used to collect data related to the intellectual capital disclosure.

\subsection{Model of empiric}

This study has measured intellectual capital based on three elements: human equity, structural equity, and relationship equity. The three elements were analyzed become one variable of intellectual capital disclosure. This model of research suggested intellectual capital disclosure has influenced negatively the cost of equity by the existence of control from enterprise measure, leverage and profitability. In addition, through the existence of proprietary cost, cost of information, and relevance of information could strengthen negative effect the was produced by disclosure of intellectual on cost of equity. Based on the explanation, it could be made an regression model equation such as the followings:

$$
\begin{aligned}
& \mathrm{COC}_{\mathrm{it}}=\mathrm{a}+\mathrm{bICD}_{\mathrm{it}}+\mathrm{e}_{\mathrm{i}} \\
& \mathrm{COC}_{i t}=\mathrm{a}+\mathrm{b}_{1} \mathrm{ICD}_{\mathrm{it}}+\mathrm{b}_{2} \mathrm{PC}_{\mathrm{it}}+\mathrm{b}_{3} \mathrm{ICD}^{*} \mathrm{PC}_{\mathrm{it}}+\mathrm{b}_{4} \mathrm{SIZE}_{\mathrm{it}}+\mathrm{b}_{5} \mathrm{PROFIT}_{\mathrm{it}}+\mathrm{b}_{6} \mathrm{LEV}_{\mathrm{it}}+\mathrm{e}_{\mathrm{it}} \\
& \mathrm{COC}_{\text {it }}=\mathrm{a}+\mathrm{b}_{1} \mathrm{ICD}_{\mathrm{it}}+\mathrm{b}_{2} \mathrm{INC}_{\mathrm{it}}+\mathrm{b}_{3} \mathrm{ICD}^{*} \mathrm{INC}_{\mathrm{it}}+\mathrm{b}_{4} \mathrm{SIZE}_{\mathrm{it}}+\mathrm{b}_{5} \text { PROFIT }_{\text {it }}+\mathrm{b}_{6} \mathrm{LEV}_{\mathrm{it}}+\mathrm{e}_{\mathrm{it}} \\
& \mathrm{COC}_{\mathrm{it}}=\mathrm{a}+\mathrm{b}_{1} \mathrm{ICD}_{\mathrm{it}}+\mathrm{b}_{2} \mathrm{INR}_{\mathrm{it}}+\mathrm{b}_{3} \mathrm{ICD}^{2} \mathrm{INR}_{\mathrm{it}}+\mathrm{b}_{4} \mathrm{SIZE}_{\mathrm{it}}+\mathrm{b}_{5} \text { PROFIT }_{\mathrm{it}}+\mathrm{b}_{6} \mathrm{LEV}_{\mathrm{it}}+\mathrm{e}_{\mathrm{it}}
\end{aligned}
$$


Effect in Sub-Group Variable:

Proprietary Cost

$$
\text { PC High: } \quad \quad \mathrm{COC}_{\mathrm{it}}=\mathrm{a}_{1}+\mathrm{b}_{1} \mathrm{ICD}_{\mathrm{it}}+\mathrm{e}_{\mathrm{it}}
$$

Cost of Information

$$
\begin{aligned}
& \text { INC High: } \quad \mathrm{COC}_{\mathrm{it}}=\mathrm{a}_{1}+\mathrm{b}_{1} \mathrm{ICD}_{\mathrm{it}}+\mathrm{e}_{\mathrm{it}} \\
& \text { INC Low: } \mathrm{COC}_{\mathrm{it}}=\mathrm{a}_{2}+\mathrm{b}_{2} \mathrm{ICD}_{\mathrm{it}}+\mathrm{e}_{\mathrm{it}}
\end{aligned}
$$

Relevance of Information

$$
\begin{aligned}
& \text { INR High: } \quad \mathrm{COC}_{i t}=\mathrm{a}_{1}+\mathrm{b}_{1} \mathrm{ICD}_{\mathrm{it}}+\mathrm{e}_{\mathrm{it}} \\
& \text { INR Low: } \mathrm{COC}_{\mathrm{it}}=\mathrm{a}_{2}+\mathrm{b}_{2} \mathrm{ICD}_{\mathrm{it}}+\mathrm{e}_{\mathrm{it}}
\end{aligned}
$$

\subsection{Operational definition of research variables}

The used independent variable in this research was intellectual capital disclosure, that was conducted on information related to capability of the employees that could be used to show the excellence of enterprise in sector of human resources. The intellectual capital disclosure was measured based on index of intellectual capital disclosure from [18] that consisted of 18 items, but the 10 items of them were included in Decision of Head of Supervisor Board of Capita Market and Financial Institution, Number: KEP-431/BL/2012 about Delivery of Annual Report of Emitten or Public Enterprise, so that the used index in intellectual capital disclosure of 8 items that showed voluntary disclosure, including the 3 items of internal equity (intellectual property, management philosophy, and information/networking systems), 3 items of external equity (brands, distribution channels, and licensing agreements), and 2 items of human equity (work related knowledge and entrepreneurial spirit).

This moderator variables were proprietary cost, cost of information, and relevance of information.Proprietary cost was the issued cost by enterprise as a consequence of the disclosure of private/internal information of enterprise, that was measured by ratio return on asset compared with return on asset of industry [39].Cost of information was the issued cost of enterprise related to the given information by enterprise to other parties that was supplied in financial report [39], that was measured using investors who have $>20 \%$ stock of enterprise.The relevance of information was suitability of supplied information in financial report with the real condition or situation. The relevance of information in this research was measured using materiality, that was valued ratio valued greater than the planning asset or duty to amount of asset in the end of fiscal year before disclosure [39].

The dependent variable in this research was cost of equity, that was issued cost of enterprise to finance fund sources from investor of equity. This cost was measured using method of ratio of price earning growth that could be accounted with the following equation [24]:

$$
\operatorname{CofE} E_{i t}=\sqrt{\frac{e p s_{t+2}-e p s_{t+1}}{P_{t}}}
$$

Symbol of $\mathrm{CofE}_{\mathrm{it}}$ represented cost equity of the implied enterprise and was measured in fiscal year of $t$; symbol eps $t_{t+1}$ represented median analyst forecast of earnings for the next year; symbol of eps ${ }_{t+2}$ represented median analyst forecast of earnings for the next two years; and symbol of Pt represented stockprice per share in years of $t$. 
The control variables in this research were size of enterprise leverage, profitability. The size was measured by the amount of enterprise assets transformed in form of natural logarithms [23]. Leverage was measured by comparing total debt with total assets. Profitability was measured by comparing profit after tax with total assets (return on investment) [24].

\subsection{Data analysis}

This research tested $\mathrm{H} 1, \mathrm{H} 2, \mathrm{H} 3$, and $\mathrm{H} 4$ using the equity of regression in formula (1). This research supported $\mathrm{H} 1$, if the equation of regression produced value of negative $\beta$ that was significant statistically. Technic of data analysis of hypothesis test of $\mathrm{H} 2, \mathrm{H} 3$, and $\mathrm{H} 4$ used the equation of regression in formula (5), (6), and (7). This research supported H2, H3, and H4 if each equation of regression produced value of $\beta$ that was significant statistically.

\subsection{Robustness test}

Based on the equation in effect in sub-group that was formed previously, it found four testing phases. First, variable of proprietary cost theory of was distributed in two groups: high and low, based on value of median from the derived data. However, test of effect in sub-group in this research has joined the two group, so that variable with high score get the value of 1 and other with low score get the value of 2. Second, result of regression analysis from high and low group then was used to account value of t-test to know the existence of effect of variable proprietary cost theory in the equation of this research. The used equation to analyze the value of t-test was such as the following [27]:

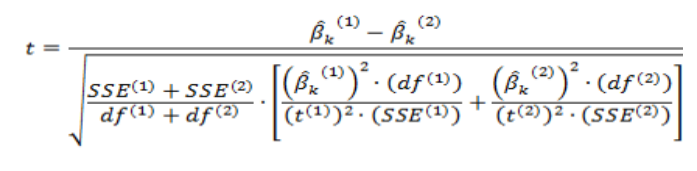

Symbol of $\widehat{\beta} k(1 / 2), \mathrm{t}(1 / 2)$, df (1/2), and SSE(1/2) represented respectively the coefficient of regression of ICD on cost of equity, the derived value of t-test, value of degree of freedom, and Sum Square of Error.

The account result then was compared with value of t-table. If the value of t-test was greater than t-table, it mean that variable of significant proprietary cost theory would strengthen the negative effect of intellectual capital disclosure on cost of equity. Third, deciding criteria of hypothesis acceptance: 1) If coefficient of t-test >t-table, hypothesis was accepted; 2) If coefficient of t-test $<\mathrm{t}$-table, it was rejected the hypothesis. Fourth, concluding the performed analysis results.

\section{Results and Discussion}

\subsection{Hypothesis test}

The first hypothesis tested effect of intellectual capital disclosure on cost of equity. Table 1 showed that value of t-test was $-1.698(>t$-table $=1.648)$ with $p$-value of $0.090(<\alpha=10 \%)$. The derived value of regression coefficient was negative $(-0.117)$. That meant that the 
hypothesis of intellectual capital disclosure influenced significantly on cost of equity was supported.

Table 1. Test result of first hypothesis

\begin{tabular}{lllll}
\hline Variable & Coef & SE & t-count & p-value \\
\hline Constanta & 0.300 & 0.084 & & \\
Intellectual Capital Disclosure & -0.117 & 0.069 & -1.698 & $0.090^{*}$ \\
Size of Entreprise & -0.004 & 0.006 & -0.576 & 0.565 \\
Profitability & -0.001 & 0.001 & -1.781 & $0.075^{*}$ \\
Leverage & -0.032 & 0.046 & -0.693 & 0.489 \\
\hline
\end{tabular}

F-count $=2.679$

Significance $=0.031 * *$

Adj $\mathrm{R}^{2}=0.012$

*** significant $1 \%$;* significant $5 \%$; $*$ significant $10 \%$

The second test was conducted to evaluate the second hypothesis $\left(\mathrm{H}_{2}\right)$, that was negative effect of intellectual capital disclosure on cost of equity in low proprietary cost was greater than high proprietary cost. The analysis result could be seen in Table 2.

Table 2. Test result of second hypothesis

\begin{tabular}{lcccc}
\hline \multicolumn{4}{c}{ Proprietary Cost in Sub-Group of Low Samples } \\
\hline Variable & Coefficient & SE & t-test & p-value \\
\hline Constanta & 0.253 & 0.155 & & \\
Intellectual Capital Disclosure & -0.321 & 0.142 & -2.253 & $0.025^{* *}$ \\
Size of Enterprise & 0.015 & 0.014 & 1.124 & 0.262 \\
Profitability & -0.002 & 0.001 & -1.241 & 0.216 \\
Leverage & -0.140 & 0.094 & -1.492 & 0.137 \\
\hline
\end{tabular}

F-test $=2.042$

p-value $=0.089^{*}$

$\operatorname{Adj} R^{2}=0.016$

\begin{tabular}{l|c|c|c|c}
\hline \multicolumn{4}{c}{ Proprietary Cost in Sub-Group of Low Samples } \\
\hline Variable & Koef & SE & t-test & p value \\
\hline Constanta & 0.267 & 0.068 & & \\
Intellectual Capital Disclosure & 0.008 & 0.050 & 0.163 & 0.871 \\
Size of Enterprise & -0.011 & 0.005 & -2.361 & $0.019^{* *}$ \\
Profitability & 0.000 & 0.000 & 0.101 & 0.919 \\
Leverage & -0.005 & 0.035 & -0.143 & 0.886
\end{tabular}

F-test $=1.573$

p-value $=0.181$

Adj $\mathrm{R}^{2}=0.008$

$* * *$ significant $1 \% ; * *$ significant $5 \% ; *$ significant $10 \%$

Based on the conducted analysis results, it could be continued with analysis of test of comparing coefficients across regressions to get value of t-test that showed the difference of low and high value of proprietary cost. The account result of t-test could be seen in Table 3 . 
Table 3. Result of test of comparing coefficients across regressions based on proprietary cost in subgroup of high and low samples

\begin{tabular}{lccc}
\hline & \multicolumn{2}{c}{ Proprietary Cost } & \multirow{2}{*}{ t-test } \\
\cline { 2 - 3 } & High & Low & \\
\hline Coefficient of regression $(\tilde{\beta} k)$ & 0.008 & -0.321 & \multirow{2}{*}{2.384} \\
t-test & 0.163 & -2.253 & \\
degree of freedom $(\mathrm{df})$ & 298 & 257 & \\
Sum Square of Error $($ SSE) & 4.495 & 23.475 & \\
\hline
\end{tabular}

The analysis result showed the value of t-test (2.384) > t-table (1.969), so that it could be said that negative effect of intellectual capital disclosure on cost of equity in low proprietary cost was greater than high proprietary cost. It meant that the hypothesis that the negative effect of intellectual capital disclosure on cost of equity in low sub-group of samples of proprietary cost was stronger than high proprietary cost that was not proven to influence significantly on cost of equity was supported.

The third test was conducted to evaluate third hypothesis $\left(\mathrm{H}_{3}\right)$, that was negative effect of disclosure of intellectual capital on cost of equity in low information was greater than high cost of information. Cost of information showed the cost issued by enterprise related to the information given by enterprise to other parties that was supplied in financial report showed on Table 4.

Table 4. Test result of third hypothesis

\begin{tabular}{|c|c|c|c|c|}
\hline \multicolumn{5}{|c|}{ Cost of Information in Sub-Group of Low Samples } \\
\hline Variable & Coefficient & SE & t-test & p-value \\
\hline Constanta & 0.357 & 0.134 & & \\
\hline Intellectual Capital Disclosure & -0.191 & 0.110 & -1.736 & $0.084 *$ \\
\hline Size of Enterprise & -0.002 & 0.011 & -0.190 & 0.849 \\
\hline Profitability & -0.001 & 0.001 & -1.078 & 0.282 \\
\hline Leverage & -0.068 & 0.077 & -0.892 & 0.373 \\
\hline \multicolumn{5}{|l|}{$\begin{array}{l}\text { F-test }=1.949 \\
p \text {-value }=0.102 \\
\text { Adj } R^{2}=0.012\end{array}$} \\
\hline \multicolumn{5}{|c|}{ Cost of Information in Sub-Group of High Samples } \\
\hline Variable & Coefficient & SE & t-test & p-value \\
\hline Constanta & 0.194 & 0.096 & & \\
\hline Intellectual Capital Disclosure & -0.031 & 0.075 & -0.420 & 0.675 \\
\hline Size of Enterprise & -0.002 & 0.007 & -0.310 & 0.756 \\
\hline Profitability & -0.001 & 0.000 & -1.768 & $0.078 *$ \\
\hline Leverage & -0.010 & 0.048 & -0.216 & 0.829 \\
\hline $\begin{array}{l}\text { F-test }=\mathbf{0 . 9 8 5} \\
p \text {-value }=\mathbf{0 . 4 1 6} \\
\text { Adj } R^{2}=0.000\end{array}$ & & & & \\
\hline
\end{tabular}

Based on analysis results it was known that intellectual capital disclosure in sub-group of low and high samples did not have significant effect in the cost of equity. If it was seen from the results, it could be known that cost of information could not strengthen the effect of the intellectual capital disclosure on cost of equity. It was strengthened by the analysis result of test 
of comparing coefficients across regressions, that was cost of information could not strengthen the effect of intellectual capital disclosure on cost of equity.

The analysis results showed that the negative effect of intellectual capital disclosure on cost of equity in sub-group of samples of low cost of information was greater than in sub-group of samples of high cost of information was not supported. Result of fourth hypothesis showed on Table 5 .

Table 5. Test result of fourth hypothesis

\begin{tabular}{|c|c|c|c|c|}
\hline \multicolumn{5}{|c|}{ Relevance of Information in Sub-Group of Low Samples } \\
\hline Variable & Coefficient & SE & t-test & p-value \\
\hline Constanta & 0.233 & 0.123 & & \\
\hline Intellectual Capital Disclosure & -0.171 & 0.113 & -1.507 & 0.133 \\
\hline Size of Enterprise & 0.005 & 0.010 & 0.545 & 0.586 \\
\hline Profitability & -0.001 & 0.001 & -1.502 & 0.134 \\
\hline Leverage & -0.086 & 0.074 & -1.162 & 0.246 \\
\hline \multicolumn{5}{|l|}{$\begin{array}{l}\mathrm{F} \text {-count }=1.551 \\
p \text {-value }=0.188 \\
\text { Adj } \mathrm{R}^{2}=0.008\end{array}$} \\
\hline \multicolumn{5}{|c|}{ Relevance of Information in Sub-Group of High Samples } \\
\hline Variable & Coefficient & SE & t-test & p-value \\
\hline Constanta & 0.379 & 0.118 & & \\
\hline Intellectual Capital Disclosure & -0.073 & 0.083 & -0.876 & 0.382 \\
\hline Size of Enterprise & -0.013 & 0.009 & -1.537 & 0.125 \\
\hline Profitability & -0.001 & 0.001 & -0.953 & 0.341 \\
\hline Leverage & 0.017 & 0.058 & 0.286 & 0.775 \\
\hline $\begin{array}{l}\text { F-test }=1.687 \\
p \text {-value }=0.153 \\
\text { Adj } R^{2}=0.009\end{array}$ & & & & \\
\hline
\end{tabular}

Based on analysis result Table 5, it was known that the intellectual capital disclosure in sub-group of low and high samples did not have significant effect on cost of equity. If it was seen from the result, it could be known that the relevance of information could not strengthen the effect of intellectual capital disclosure on cost of equity. It was strengthened by analysis result of test of comparing coefficients across regressions that was conducted that the relevance of information could not strengthen the effect of the intellectual capital disclosure on cost of equity. The analysis result showed that hypothesis that the negative effect of the intellectual capital disclosure on cost of equity in sub-group of samples of high relevance of information was greater than low relevance of information was not supported.

\subsection{Sensitivity analysis}

The next analysis was analysis of dummy, that analyzed the kind of industry of sampled enterprises and the period of years that was used in research as variable of control. Based on Table 6, it was known that from some kinds of enterprise industry that became samples had significant value of smaller than 0.05 . The kinds of industry were Basic Industry and Chemicals (I3) with significance of $0.036(<0.05)$, Miscellaneous Industry (I4) with significance of 0.006 $(<0.05)$, and infrastructure, Utilities and Transportation (I7) with significance of $0.000(<0.05)$. Whereas in the period of years, there was not significant period in cost of equity. 
Table 6. Test Result of Dummy Based on Kind of Industry and Period of Years

\begin{tabular}{lcccc}
\hline Variable & Coef & SE & t-count & p-value \\
\hline Constanta & 0.289 & 0.091 & & \\
Intellectual Capital Disclosure & -0.078 & 0.073 & -1.063 & 0.288 \\
Size of Entreprise & -0.007 & 0.007 & -1.108 & 0.268 \\
Profitability & -0.001 & 0.001 & -1.265 & 0.207 \\
Leverage & -0.055 & 0.046 & -1.205 & 0.229 \\
Agriculture (I1) & 0.046 & 0.049 & 0.952 & 0.341 \\
Mining (I2) & 0.095 & 0.053 & 1.794 & $0.073^{*}$ \\
Basic Industry and Chemicals (I3) & 0.060 & 0.029 & 2.107 & $0.036^{* *}$ \\
Miscellaneous Industry (I4) & 0.102 & 0.037 & 2.760 & $0.006^{* * *}$ \\
Consumer Goods Industry (I5) & 0.009 & 0.037 & 0.254 & 0.800 \\
Property. Real Estate and & 0.019 & 0.027 & 0.692 & 0.489 \\
Building Construction (I6) & & & & \\
Infrastructure, Utilities and & 0.193 & 0.042 & 4.583 & $0.000^{* * *}$ \\
Transportation (I7) & & & & \\
\hline Year of 2013 (T1) & 0.028 & 0.030 & 0.940 & 0.347 \\
Year of 2014 (T2) & 0.024 & 0.030 & 0.806 & 0.421 \\
Year of 2015 (T3) & -0.021 & 0.030 & -0.701 & 0.484 \\
Year of 2016 (T4) & -0.010 & 0.030 & -0.347 & 0.729 \\
\hline F-count 2.974 & & & & \\
\hline
\end{tabular}

F-count $=2.974$

Significansce $=0.000^{* *}$

$\operatorname{Adj} R^{2}=0.050$

$* * *$ significant $1 \%$;* significant $5 \%$; significant $10 \%$

Analysis of interaction was performed to know the factor from which proprietary cost (proprietary cost, cost of information, and relevance of information) that could strengthen the negative effect of the intellectual capital disclosure on cost of equity. The test result of interaction could be seen in Table 7, Table 8, and Table 9.

Table 7. Test Result of Interaction of Intellectual Capital Disclosure with Proprietary Cost

\begin{tabular}{llllr}
\hline Variable & Coe & SE & t-count & p-value \\
\hline Constanta & 0.318 & 0.085 & & \\
Intellectual Capital Disclosure & -0.159 & 0.076 & -2.078 & 0.038 \\
Size of Entreprise & -0.003 & 0.007 & -0.382 & 0.702 \\
Profitability & -0.001 & 0.001 & -1.541 & 0.124 \\
Leverage & -0.037 & 0.047 & -0.790 & 0.430 \\
Proprietary Cost & -0.018 & 0.014 & -1.278 & 0.202 \\
Interaction of ICD*Proprietary Cost & 0.022 & 0.018 & 1.265 & 0.206 \\
\hline F hitung = 2.057 & & & & \\
$p$ value $=0.057 *$ & & & & \\
Adj $\mathrm{R}^{2}=0.011$ & & & &
\end{tabular}

Based on Table 7, it was known that from the value of significance that was derived from interaction between the intellectual capital disclosure (ICD) with proprietary cost was 0.206. The value was greater than 0.05 . it meant that influencing not significantly. It showed that proprietary cost in this research was not good moderator variable, that meant that proprietary cost could not strengthen the negative effect of intellectual capital disclosure on cost of equity. 
Table 8. Test Result of Interaction of Intellectual Capital Disclosure with Cost of Information

\begin{tabular}{lllll}
\hline \multicolumn{1}{c}{ Variable } & Coefficient & SE & t-count & p-value \\
\hline Constanta & 0.355 & 0.109 & & \\
Intellectual Capital Disclosure & -0.192 & 0.114 & -1.682 & 0.093 \\
Size of Entreprise & -0.004 & 0.007 & -0.599 & 0.549 \\
Profitability & -0.001 & 0.001 & -1.755 & 0.080 \\
Leverage & -0.034 & 0.046 & -0.723 & 0.470 \\
Cost of Information & -0.129 & 0.181 & -0.714 & 0.476 \\
Interaction of ICD*Cost of Information & 0.184 & 0.226 & 0.816 & 0.415 \\
\hline F-count $=1.921$ & & & & \\
p-value $=0.075^{*}$ & & & & \\
Adj R2 $=0.010$ & & & & \\
\hline
\end{tabular}

*** significant $1 \%$; ** significant $5 \%$; $*$ significant $10 \%$

Based on Table 8, it was known from value of significance that was derived from interaction of intellectual capital disclosure (ICD) with cost of information was 0.415 . The value was higher than 0.05 , it meant not influencing significantly. It showed that cost of information in this research was not good moderator variable, it meant cost of information could not strengthen the negative effect of intellectual capital disclosure on cost of equity.

Table 9. Test Result of Interaction of Intellectual Capital Disclosure with Relevance of Information

\begin{tabular}{lcccc}
\hline Variable & $\begin{array}{c}\text { Coefficien } \\
\mathbf{t}\end{array}$ & SE & t-count & p-value \\
\hline Constanta & 0.300 & 0.084 & & \\
Intellectual Capital Disclosure & -0.119 & 0.069 & -1.733 & 0.084 \\
Size of Entreprise & -0.003 & 0.007 & -0.521 & 0.602 \\
Profitabilitas & -0.001 & 0.001 & -1.794 & 0.073 \\
Leverage & -0.035 & 0.046 & -0.760 & 0.448 \\
Interaction of ICD*Relevance of Information & -0.001 & 0.001 & -0.733 & 0.464 \\
\hline F hitung $=2.249$ & & & & \\
p value $=0.048^{* *}$ & & & & \\
Adj R2 =0.011 & & & &
\end{tabular}

Based on Table 9, it was known that from value of significance that derived from interaction of intellectual capital disclosure (ICD) with the relevance of information of 0.464 . The value was greater than 0.05 , it meant that not influencing significantly. It showed that the relevance of information in this research was not good moderator variable, that meant this relevance of information could not strengthen the negative effect of intellectual capital disclosure on cost of equity.

\subsection{Discussion}

Cost of equity was measurement at the level of discount where the market could apply to the cash flow of the future that was expected by enterprise to decide the current stock price [33]. Cost of equity was used to make decision that could be made to enterprise interest. The high cost of equity could make the enterprise to increase the performance, because the fund could be used to enterprise operational or product development, used to cover the costing fund of equity 
supply. [38] explained that financial disclosure was related negatively with cost of equity. The containing information in financial report could decrease the loaded cost of equity, because in the financial report contained important informations that could increase value of enterprise compared the competitor enterprises. [12] have tested empirically the effect of intellectual capital disclosure on cost of equity. Intellectual capital disclosure was important private information [1], so that it could be used as basic of investment decision, decreasing estimation risks, achieve the right stockprice, and decreasing cost of equity.

The test results empirically showed that the more complete capital disclosure could decrease cost of equity of enterprise. It was appropriate with the statement of [16], that the increase of public information disclosure could decrease cost of equity of enterprise. The test result in this research was not appropriate with the research conducted by [31], where the research found that the historical intellectual capital disclosure gave positive effect on cost of equity. The historical information made reference to information related to project or program conducted by enterprise and has been listed in the enterprise policy and strategy to compete with other enterprises, so that this information was need to be voluntary disclosure to increase the quality of disclosure in annual report of the enterprise.

Nevertheless, the empirical test result in this research was also in line with some previous results the research [9][10][35][44][12][29][32][33]. The research results have found that intellectual capital disclosure with the disclosure completeness could decrease cost of equity. The conducted intellectual capital disclosure could show that enterprise had capability to manage and develop the enterprise.

Proprietary cost theory [47] explained the importance of proprietary cost existence. The proprietary cost has become a cause of decreasing information quality that was disclosured by enterprise. The higher proprietary cost, the lower the accuracy of information that was disclosured [2]. It meant that proprietary cost influenced the relationship of information disclosure [39], because the amount of issued cost showed the amount of disclosure that was conducted by enterprise.

The empirical result in this research showed that low proprietary cost could make negative effect of intellectual capital disclosure on cost of equity to be greater. The research result was in line with the research conducted by [25], showed that proprietary cost could give negative effect to voluntary disclosure conducted by management, it meant that through low proprietary cost the enterprise could increase voluntary disclosure in financial report.

However, the empirical test result in this research has failed to prove that low cost of information could make negative effect given by intellectual capital disclosure on cost of equity to be greater. Many disclosured information impacted on great cost to disclosure the information. Nevertheless, the great cost was not directly impact on cost of equity. Quality of disclosure related to cost and benefit of information was similar to the quality in proprietary cost theory [45]. The qualified information disclosure needed the professional persons, whereas to get the professional persons needed additional cost. It could be possible if the enterprise did not consider information cost that was the responsibility in intellectual capital disclosure [25][30], but rather the impact caused by intellectual capital disclosure in the owned low cost of equity.

Nevertheless, this empirical test result has failed to prove the proprietary cost theory, that was in relevance of information that showed that high relevance of information could not make negative effect of intellectual capital disclosure on cost of equity to be greater. It could be caused of the relevance of an information in intellectual capital disclosure in some enterprises were not main factor to be considered in increasing value of enterprise, but more to information with value that could increase the value of enterprise. [13] has mentioned that asymmetry of information in supplied annual report could be caused by trading volume, stock price, and 
volatility of stock return. The asymmetry of information could make problem, because of the different understanding of financial report [3]. The difference to understand the report could give effect in different assessment by external with internal parties to the supplied report, so the assessment to enterprise performance could also differ according to the understanding of the party that interpreted the financial report.

\section{Conclusion}

Based on the empirical test result, the first hypothesis (H1) explained that intellectual capital disclosure influenced negatively on cost of equity. The test result of second hypothesis (H2) showed that the low proprietary cost could make negative effect of intellectual capital disclosure on cost of equity to be greater compared than high proprietary cost. The test result of third hypothesis (H3) showed that both in sub-group of high and low samples could not strengthen the negative effect of intellectual capital disclosure on cost of equity that meant reject H3. The test result of fourth hypothesis (H4) showed that both in sub-group of high and low samples could not strengthen the negative effect of intellectual capital disclosure on cost of equity, then meant reject $\mathrm{H} 4$.

Based on the conclusion, the theoretical implication of this research strengthened the existing theory of signaling, that was the intellectual capital disclosure influenced negatively on cost of equity, that meant the more complete the intellectual capital disclosure could surprise the cost of equity. In addition, this study results also proven that proprietary cost theory, that was low proprietary cost, could strengthen negative effect given by intellectual capital disclosure on cost of equity, it meant that enterprise with low proprietary cost tended to disclosure the intellectual capital more completely, and it could suppress cost of equity. Practical implication of this study could be used as matter of consideration for enterprise management to suppress cost of equity. This research result showed that increasing the intellectual capital disclosure voluntarily could decrease cost of equity. Nevertheless, management was also need to classify and consider which information that could increase the quality of financial report. The performed intellectual capital disclosure was certainly based on information that was assumed to be important and could give benefit for enterprise, such as the used system of information and the owned resources and make differ from other enterprises, so that it could decrease cost of equity, and analyzing the risks that could be experienced and deciding the follow-up as anticipation with the performed disclosure. In addition, the research results also showed that proprietary cost could strengthen the effect of intellectual capital disclosure on decreasing cost of equity. Therefore, management could suppress the proprietary cost in order to intellectual capital could be disclosured in financial report, so that it could impact on decreasing cost of equity.

This study has limitation in the period of analysis, that is limited to the number of enterprises. The enterprise samples in this research were consisted of multiple sectors of industry, such as manufacture, mining, agriculture, basic and chemical industry, multiple industries, industry of consumption goods, property and infrastructure, so that it is possible to experience bias from the derived results. Therefore, this research could not see the role of signaling theory and proprietary cost theory in effects of intellectual capital disclosure for each sector of industry. 


\section{References}

[1] Aboody, D. and Lev, B. (2000). Information asymmetry, R\&D, and insider gains. The Journalof Finance, Vol. LV No. 6, 2747-66.

[2] Admati, A. And Pfleiderer, P. (2000). Forcing Firmsto Talk: Financial Disclosure Regulationand Externalities. Reviewof Financial Studies, Vol. 13, Issue 3, 479-519.

[3] An, Y., Davey, H. and Eggleton, I. R. C. (2011). Towards a Comprehensive Theoretical Framework for Voluntary IC Disclosure. Journal of Intellectual Capital, Vol. 12, No. 4, 571-585.

[4] Ayeni, T. M. and Olaoye, B. J. (2015). Cost of capital theory and firm value: Conceptual perspective. International Journal of Multidisciplinary Researchand Development, Vol. 2, Iss. 10, 632-636.

[5] Beattie, V. and Smith, S. J. (2013). Value Creationand Business Models: Refocusing the Intellectual Capital Debate. British Accounting Review, 45 (4), 243-254.

[6] Beattie, V. and Thomson, S.J. (2006). Liftingthe Lid onthe Use of Content Analysis to Investigate Intellectual Capital Disclosures. Paper. School of Management and Languages Heriot-Watt University Edinburgh.

[7] Bertomeu, J., Beyer, A., and Dye, R. A. (2011). Capital structure, costofcapital, and voluntary disclosures. AccountingReview, 86(3), 857-886.

[8] Birjandi, H., Hakemi, B., andSadeghi, M. M. M. (2015). The Study Effect Agency Theory and Signalling Theory on the Level of Voluntary Disclosure of Listed Companies in Tehran Stock Exchange. Research Journal of Finance and Accounting, Vol. 6, No. 1, 174-183.

[9] Botosan, C.A. (1997). Disclosure Level and the Cost of Equity Capital. The Accounting Review, Jul $1997 ; 72,3,323-349$.

[10] Botosan, C.A. (2006). Disclosure and The Cost of Capital: What Do We Know?. Accounting and Business Research, 36:sup1, 31-40.

[11] Botosan, C.A. and Plumlee, M. A. (2002). A Re-examinationof Disclosure Level and the Ecpected Cost of Equity Capital. Journal of Accounting Research, Vol. 40, No. 1, 21-40.

[12] Boujelbene, M.A. and Affes, H. (2013). The impact of intellectual capital disclosure on cost of equity capital: A case of French firms. Journal of Economics, Finance and Administrative Science, 18 (34), 45-53.

[13] Boujelbene, Y. and Besbes, L. (2012). Determinants of information Asymmetry between managers and investors: a study on panel data. IBIMA Business Review, Vol. 2012, 1-11.

[14] Chakroun, I. S., and Hamdouni, A. (2010). Information Costs in Financial Markets: Evidence From the Tunisian Stock Market. The Journal of Risk Finance, Vol. 11, No. 4, 401-409.

[15] Cheynel, E. (2013). A theory of voluntary disclosure and cost of capital. Review of Accounting Studies, 18(4), 987-1020.

[16] Christensen, P. O., De La Rosa, L. E., and Feltham, G. A. (2010). Information and the cost of Capital: An Exanteperspective. AccountingReview, 85(3), 817-848.

[17] Dos Santos, M. A. C., and Cavalvante, P. R. (2014). Effect of the Adoptionof IFRS on the Information Relevance of Accounting Profits in Brazil. R. Cont. Fin. - USP, Sao Paulo, Vol. 25, No. 66, 228-241.

[18] Dumay, J. and Cai, L. (2015). Using Content Analysis as a Research Methodology for Investigating Intellectual Capital Disclosure: A Critique. Journal of Intellectual Capital, Vol. 16, No. 1, 121-155.

[19] Eddine, C.O.H., Abdullah, S.N., Hamid, F.A., and Hossain, D.M. (2015). The Determinants of Intellectual Capital Disclosure: a meta-analysis review. Journal of Asia Business Studies, Vol. 9, No. 3, 232-250.

[20] Embong, Z., Saleh, N. M., and Hassan, M. S. (2012). Firm Size, Disclosure and Cost of Equity Capital. Asian Review of Accounting, Vol. 20, No. 2, 119-139.

[21] Espinosa, M. and Trombetta, M. (2007). Disclosure interaction sand the cost of equity capital: Evidence from the Spanish Continuous Market. Journal of Business Finance and Accounting, 34, 1371-1392.

[22] Gujarati, D. (2008). Ekonometrika Dasar. Alih bahasa: Sumarno Zain. Jakarta: Erlangga.

[23] Hae Young Byun, Su Keun Kwak, Lee Seok Hwang. (2008). The implied cost of equity capital and corporate governance practices. Asia-Pacific Journal of Financial Studies, Vol. 37, No. 1, 139-184. 
[24] Hao, L., Zhang, J. H, and Fang, Jing (Bob). (2014). Does voluntary adoption of XBRL reduce cost of equity capital? International Journal of Accounting and Information Management, Vol. 22 Issue: 2, 86-102

[25] Healy, P. M. and Palepu, K. G. (2001). Information Asimmetry, Corporate Disclosure, and the Capital Markets: A Review of the Empirical Disclosure Literature. Journal of Accounting and Economics, Vol. 31, 405-440.

[26] Ikatan Akuntan Indonesia. (2013). Ezposure Draft Pernyataan Standar Akuntansi Keuangan: Investasi pada Entitas Asosiasi dan Ventura Bersama. Jakarta: Dewan Standar Akuntansi Keuangan.

[27] Jogiyanto. (2004). How Why and When Investors Revise Their Beliefs To Company Information. Yogyakarta: Andi.

[28] Keputusan Ketua Badan Pengawas Pasar Modal dan Lembaga Keuangan Nomor: KEP-431/BL/2012 tentang Penyampaian Laporan Tahunan Emiten atau Perusahaan Publik.

[29] Khlif, H., Samaha, K., and Azzam, I. (2015). Disclosure, ownership structure, earnings announcement lag and cost of equity capital in emerging markets: The case of the Egyptian stock exchange. Journal of Applied Accounting Research, Vol. 16 Issue: 1, 28-57.

[30] Kowalewska, W. (2015). Advantages and Disadvantages of Voluntary Disclosure of Companies. Universitat Autonomade Barcelona.

[31] Kristandl, G. andBontis, N. (2007). The impact of voluntary disclosure on cost of equity capital estimates in a temporal setting. Journal of Intellectual Capital. Vol. 8 No. 4, 2007. pp. 577-594.

[32] Mangena, M., Jing Li and Tauringana, V. (2016). Disentangling the Effects of Corporate Disclosure on the Cost of Equity Capital: A Study of the Role of Intellectual Capital Disclosure. Journal of Accounting, Auditing \& Finance, 31(1), pp. 3-27.

[33] Mangena, M., Pike, R., and Jing Li. (2010). Intellectual Capital Disclosure Practices and Effects on the Cost of Equity Capital: UK Evidence. Edinburgh: The Instituteof Chartered Accountants of Scotland.

[34] Mosavi, S.A., Nekoueizadeh S., \&Ghaedi, M. (2012). A Study of Relations Between Intellectual Capital Components, Market Valueand Finance Performance. African Journal of Business Management. Vol. 6 (4), pp. 1396-1403,1 February, 2012.

[35] Orens, R., Aerts, W., and Lybaert, N. (2009). Intellectual capital disclosure, cost of finance and firm value. Management Decision. Vol. 47 No. 10, 2009 pp. 1536-1554.

[36] Prencipe, A. (2004). Proprietary costs and determinants of voluntary segment disclosure: evidence from Italian listed companies, European Accounting Review, 13:2, 319-340.

[37] Rajeh, M. (2014). Impact of Procurement Systems on Transaction Costs: A Structural Equation Modelling Methodology. New Zealand Built Environment Research Symposium.

[38] Richardson, A. J. and Welker, M. (2001). Social disclosure, financial disclosure and the cost of equity capital. Accounting, Organisations and Society, 26, 597-616.

[39] Scott, T. W. (1994). Incentives and Disincentives for Financial Disclosure: Voluntary Disclosureof Defined Benefit Pension Plan Information by Canadian Firms. The Accounting Review, Vol. 69, No. 1, 26-43.

[40] Shamki, D. (2014). Owners' Equity and Accounting Information Relevance. Procedia-Social and Behavioral Sciences 164, 194-200.

[41] Shehata, N. F. (2014). Theories and Determinants of Voluntary Disclosure. Accounting and Finance Research, Vol. 3, No. 1, 26.

[42] Sirait, S. D. Y. dan Siregar, S. V. (2012). Hubungan Antara Kos Modal Ekuitas dengan Tingkat Pengungkapan Tanggung Jawab Sosial dan Modal Intelektual pada Sektor Perbankan di Indonesia. Jurnal Akuntansi \&Auditing, Vol. 9, No. 1, pp. 70-85.

[43] Sonnier, B.M. (2008). Intellectual capital disclosure: high-tech versus traditional sector companies. Journal of Intellectual Capital. Vol. 9 No. 4, pp. 705-722

[44] Souissi, M. and Khlif, H. (2012). Meta-analytic review of disclosure level andcost of equity capital. International Journal of Accounting and Information Management. Vol. 20 No. 1, 2012,. 49-62.

[45] Sulaiman, M., Abdullah, N., and Fatima, A. H. (2014). Determinants of Environmental Reporting Quality in Malaysia. International Journal of Economics, Management and Accounting, Vol. 22, No. 1, 63-90. 
[46] Taliyang, S. M., Harun, R. J., Mustafa, N. H., and Mansor, M. (2014). Intellectual Capital Disclosure and Market Capitalization. International Journal of Business and Social Science, Vol. 5, No. 10, 96102.

[47] Verrecchia, R. (1983). Discretionary disclosure. Journal of Accounting and Economics 5, 179-194. 